Research paper

\title{
Forest restoration assessment in Brazilian Amazonia: A new clustering-based methodology considering the reference ecosystem
}

\author{
Felipe H. Fengler ${ }^{\mathrm{a}, *}$, Adriano Bressane ${ }^{\mathrm{a}}$, Marcela M. Carvalho ${ }^{\mathrm{a}}$, Regina M. Longo ${ }^{\mathrm{b}}$, \\ Gerson A. de Medeiros ${ }^{\mathrm{a}}$, Wanderley J. de Melo ${ }^{\mathrm{c}}$, Catarina C. Jakovac ${ }^{\mathrm{d}}$, Admilson I. Ribeiro ${ }^{\mathrm{a}}$ \\ a São Paulo State University (UNESP), Institute of Science and Technology, Sorocaba, 18087-180, Brazil \\ b Pontifical Catholic University of Campinas, Campinas, 13086-900, Brazil \\ c Brazil University, Descalvado, 13690-000, Brazil \\ d International Institute for Sustainability, Rio de Janeiro, 22460-320, Brazil
}

\section{A R T I C L E I N F O}

\section{Keywords:}

Restoration ecology

Land reclamation

Surface mining

Richness

Natural regeneration

Methodological proposal

\begin{abstract}
A B S T R A C T
Techniques for forest restoration have been widely developed over the past decades, allowing the reestablishment of vegetation in extreme cases such as surface mining. However, there are still issues related to management and monitoring that require further understanding, especially concerning comparisons with reference ecosystems. In this study, hierarchical agglomerative clustering (HAC) with uncertainty estimation is proposed as a methodology for forest restoration assessment. For this purpose, analysis was made of phytosociological variables for 27 plots located in reforested closed mines and in the Amazon forest reference ecosystem. The technique grouped the reference ecosystem separately from the reclamation sites. The HAC was affected by dependency among the analyzed variables, and heterogeneity was observed for all the phytosociological parameters in the cluster groups formed by the mining locations. However, each group showed specific characteristics related to the different environmental conditions and the forest restoration performance. The results demonstrated that HAC with uncertainty estimation was more suitable for defining groups, compared to the classical approach, offering a promising methodology for evaluation of the outcomes of forest restoration and for guiding management actions in disturbed tropical forests.
\end{abstract}

\section{Introduction}

Mining activities are responsible for almost $4 \%$ of the gross domestic product of Brazil, corresponding to U\$ 85 billion in 2013, with a U\$ 27.4 billion budget surplus attributed to this activity alone (ICMM, 2013). However, despite all the economic and social benefits associated with this sector, the exploitation of mineral reserves in important ecosystems, such as the Amazon Forest, requires careful management in order to avoid negative environmental impacts and associated problems (Phillips, 2016; Souza et al., 2011; Monteiro, 2005; Pedlowski et al., 1997; Smith et al., 1991).

In surface mining, especially, there are the creation of huge overburden dumps and voids, which mostly consist of large boulders and loose rock fragments, devoid of organic matter and nutrients (Mukhopadhyay et al., 2014). In these situations, considerable restoration effort is required to reestablish the preexisting multi-scale ecosystem processes, or a condition close to them (Parrotta and Knowles, 2001).
Even with prior planning, the different levels of landscape modification, together with different forms of exploitation, the reclamation methods adopted, and availability of financial resources, are determining factors of the new environment formed, which can differ from the characteristics of the original ecosystem (Stanturf et al., 2014; Li et al., 2006; Parrotta and Knowles, 2001; Miao and Marrs, 2000; Bradshaw, 2000, 1997; Bradshaw, 1984).

Since these ecosystems present high levels of complexity, both qualitative and quantitative, the evaluation of restored environments and the outcomes of land reclamation remains a very difficult task, especially in terms of understanding how to measure it and how to know when the reclamation ends (Leinfelder et al., 2015). Considering forest restoration, comparison with reference ecosystems has been highlighted as a crucial aspect, since it can provide criteria to evaluate the outcomes of actions performed and identify existing technical limitations that may not allow a full restoration (Rosenfield and Müller, 2017; Lei et al., 2016; Ribeiro et al., 2016).

There has been a great effort in the scientific community to debate

\footnotetext{
* Corresponding author at: Programa de Pós-graduação em Ciências Ambientais do Instituto de Tecnologia de Sorocaba (UNESP Sorocaba), Avenida Três de Março 511, Sorocaba, SP, 18087-180, Brazil.

E-mail addresses: felipe_fengler@hotmail.com, felipe.fengler@posgrad.sorocaba.unesp.br (F.H. Fengler).
} 
forest restoration concepts (Lima et al., 2016; Balaguer et al., 2014) and techniques (Ribeiro et al., 2015; Stanturf et al., 2014; Rodrigues et al., 2009), in some cases with narrow scopes only valid for local conditions (Young et al., 2003). Future challenges involving ecological restoration will require measurement and monitoring methods that are more comprehensive, enabling evaluation of whether the ecosystem function is developing towards the desired state (Halme et al., 2013).

The aim of the present work was to explore this topic, with proposal of a clustering-based methodology for forest restoration assessment. A case study was employed to test the technique, evaluating the phytosociological variables and soil characteristics of forest restoration projects at seven deactivated mines in Brazilian Amazonia. Hierarchical agglomerative clustering (HAC) was employed because it is one of the simplest clustering methods, is generally applicable to most types of data, does not require extensive prior knowledge, and enables results to be easily visualized graphically in the form of dendrograms (Legendre and Legendre, 2012; Romesburg, 2004; Jongman et al., 1995). The methodology included a robust routine constructed using the R software Pvclust (Suzuki and Shimodaira, 2015, 2006), with estimation of uncertainty in the cluster analyses in order to improve evaluation of the results.

This work was based on the hypothesis that HAC with uncertainty estimation could be a useful tool to evaluate tropical forest restoration, allowing the identification of driving forces, technical limitations in restoring complex forests, and management elements.

\section{Materials and methods}

\subsection{Study location}

Jamari National Forest is located in the municipality of Itapuã do Oeste, in Rondônia State, Brazil (latitude $09^{\circ} 00^{\prime} 00^{\prime \prime} \mathrm{S}, 09^{\circ} 30^{\prime} 00^{\prime \prime} \mathrm{S}$; longitude $62^{\circ} 44^{\prime} 05^{\prime \prime} \mathrm{W}, 63^{\circ} 16^{\prime} 54^{\prime \prime} \mathrm{W}$ ) (Fig. 1). The total area is 215,000 ha, of which $90 \%$ is covered by open tropical rainforest (Amazon biome) and $10 \%$ consists of mining areas, with one operating mine and seven other deactivated in the process of reclamation.

The climate is tropical rainy (Aw, according to the Köppen scale), with a well-defined dry season in winter, from July to August, and a rainy season in summer, from December to March (Ribeiro et al., 2016). The main soils are dystrophic Red-Yellow Latosol (Kandiudult) and dystrophic Red-Yellow Podzolic (Paleudult), covered by open rainforest with small patches of tropical rainforest, characterized by a high richness of spaced arboreal individuals and a diverse wildlife, including several species threatened with extinction (MMA/IBAMA, 2005; Soil Survey Staff, 1999).

\subsection{Treatments description}

The study was undertaken at seven deactivated mines, previously used for cassiterite extraction, which have been under reclamation since the 1990s, aiming at reestablishment of the dominant Amazonia landscape. Due to the heterogeneity of the mined soil, an environmental zoning of the post-mining locations was performed before site preparation and initiation of activities, employing a preliminary environmental damage assessment (Ribeiro et al., 2015). All the soil substrates of the deactivated mines were previously classified into three main environmental zones, according to their physical and chemical characteristics:

[1] Pit mine: Soil substrate obtained due to earthworks in surface soil, following exposure of the slopes, construction of berms, construction of access roads, and other operations requiring the excavation, removal, or landfill of surface soil. This substrate maintained the characteristics closest to those of the original soil.

[2] Tailings (dry and wet): Remnant substrate composed of a heterogeneous mass of material derived from the filling of ore removal locations. These areas were filled with sediment of variable grain size and were drained or partially drained, subject to flooding, and devoid of organic matter. The characteristics of this substrate depended on the physical and geochemical properties of the rock from which it derived, but it was usually nutrient-poor and supported little plant growth. The dry tailings were located near the containment dam, having large particle size (mainly sand), little or no soil structure, low or very low natural fertility, excessive drainage capacity, and low water retention capacity. The wet tailings were away from the dam containment, usually near watercourses, with a tendency for fine particle sizes and a predominance of clay. Due to their proximity to watercourses, these tailings could remain flooded for part of the year.

[3] Capped tailings: Substrates formed by the covering of tailings with topsoil. The topsoil was usually obtained from other locations where mines were in the process of being opened, and therefore contained organic matter and seeds, favoring the reestablishment of vegetation. As tailings are highly erodible, with adverse effects on plant growth and in water courses, this procedure has become a requirement in recent Brazilian environmental laws. As a result, this substrate tended to have better physical and chemical characteristics, compared to the dry and wet tailings, although such characteristics were nonetheless highly dependent on the properties of the deposited material.

Following the environmental damage assessment, actions that were implemented prior to revegetation with native species included topographic reconstruction, control of runoff, and soil restoration, using composting associated with green manuring, chemical fertilizers, and liming, depending on the characteristics and extent of the environmental damage at each site (Ribeiro et al., 2015; Yada et al., 2015; Longo et al., 2011).

\subsection{Floristic structure and composition}

A total of 91 planted species, belonging to 37 families, were used in the forest restoration of the overburdens. Of all species, 22 were exclusively of natural regeneration, representing $29 \%$ of the total sampled individuals. The botanical families with the greatest numbers of individuals were Fabaceae, Myrtaceae, and Clusiaceae, with the first two also showing the highest number of species. Members of families that were not planted, including Cecropiaceae, Clusiaceae, Cannabaceae, Malvaceae, Melastomataceae, Moraceae, Piperaceae, and Siparunaceae, were found in the mined areas as well as in the natural forest. The most common species were Inga laurin and Syzygium cumini, both with high density, due to their extensive use in the revegetation process, while among the naturally regenerated individuals, the most common species were Bellucia grossularioides, Astrocarium aculeatum, and Trema micrantha.

\subsection{Data collection}

The study was performed using 19 plots (each measuring $50 \times 50 \mathrm{~m}$ ) located in the north-south direction from the access roads. The data were collected in 2010, in areas with different planting ages ranging from 3 to 9 years (Table 1). In addition, 8 plots in the surrounding areas, in closed canopy forest (undisturbed Amazon forest) and open canopy forest (disturbed Amazon forest), were adopted as reference ecosystems and were used to assess the performance of the forest restoration, with data also collected in 2010 .

The average height was measured for trees with diameter at breast height (DBH) greater than $10 \mathrm{~cm}$. Basal area (Eq. (1)), average species richness, and number of naturally regenerating individuals were obtained by counting trees with DBH smaller than $10 \mathrm{~cm}$. The average species richness was obtained by calculating the total species sampled in $50 \times 50 \mathrm{~m}$ plots, and the number of naturally regenerating individuals was obtained by counting the number of naturally occurring tree seedlings with height smaller than $3 \mathrm{~cm}$ in $10 \times 10 \mathrm{~m}$ plots, positioned inside the $50 \times 50 \mathrm{~m}$ plots. The same variables were measured in secondary (open canopy) and mature (closed canopy) forests in the 


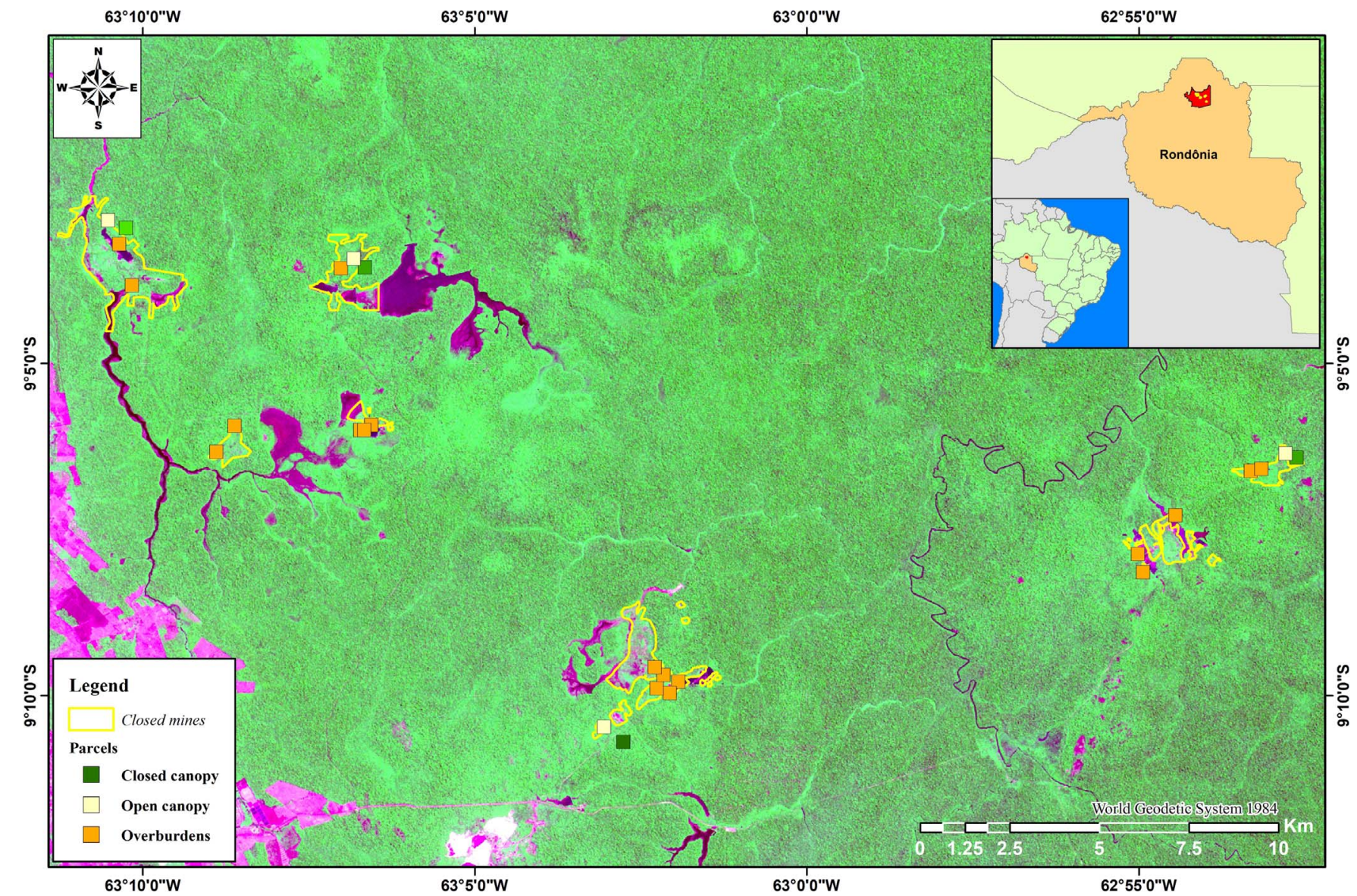

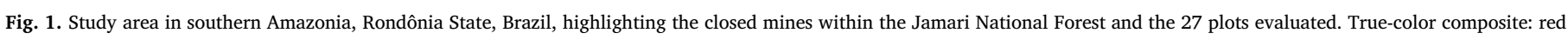

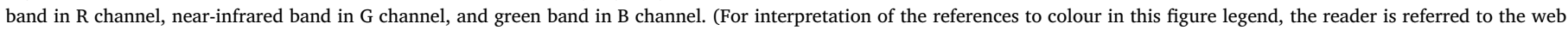
version of this article.)

Source: CBERS 4 scene 175/110 of September 17, 2015 (INPE, 2015).

areas surrounding the closed mines (Fig. 1). In the case of naturally regenerating individuals, the units were converted to regenerating individuals per square meter, in order to facilitate interpretation of the results and comparison with the natural reference.
$B A=\frac{2 \pi \times D B H}{4}$

where $B A$ is the basal area and $D B H$ is the diameter at breast height. For individuals with bifurcated trunk, $B A$ was calculated as the sum of the basal areas of each trunk.

Table 1

Main characteristics of the sampled locations.

\begin{tabular}{|c|c|c|c|c|c|c|c|c|}
\hline \multirow[t]{2}{*}{ Sites } & \multirow[t]{2}{*}{ Substrate } & \multirow[t]{2}{*}{ Planting age in 2010 (years) } & \multicolumn{5}{|c|}{ Substrate fractions (\%) } & \multirow[t]{2}{*}{ Soil organic matter $\left(\mathrm{g} / \mathrm{dm}^{3}\right)$} \\
\hline & & & Clay & Silt & Very fine sand & Medium sand & Coarse sand & \\
\hline Site 1 - Mine 1 & Dry tailing & 8 & 7.9 & 4.8 & 58.9 & 18.2 & 10.2 & 16.7 \\
\hline Site 2 - Mine 1 & Dry tailing & 9 & 19.6 & 6.0 & 41.0 & 14.5 & 18.9 & 21.3 \\
\hline Site 3 - Mine 1 & Dry tailing & 4 & 14.6 & 1.6 & 28.4 & 32.8 & 22.6 & 5.3 \\
\hline Site 1 - Mine 2 & Capped tailing & 3 & 15.6 & 10.3 & 28.9 & 29.8 & 4.6 & 23.3 \\
\hline Site 2 - Mine 2 & Dry tailing & 5 & 13.1 & 2.1 & 31.3 & 28.0 & 25.5 & 11.0 \\
\hline Site 1 - Mine 3 & Wet tailing & 3 & 16.1 & 6.0 & 37.1 & 28.8 & 12.0 & 14.7 \\
\hline Site 2 - Mine 3 & Wet tailing & 9 & 14.9 & 5.7 & 43.5 & 22.6 & 13.3 & 12.3 \\
\hline Site 1 - Mine 4 & Dry tailing & 9 & 17.5 & 6.3 & 45.5 & 22.6 & 8.1 & 19.3 \\
\hline Site 1 - Mine 5 & Wet tailing & 7 & 14.6 & 6.0 & 36.8 & 25.7 & 14.2 & 9.0 \\
\hline Site 2 - Mine 5 & Wet tailing & 6 & 13.8 & 5.4 & 50.0 & 16.4 & 14.6 & 8.7 \\
\hline Site 1 - Mine 6 & Pit mine & 8 & 34.5 & 8.4 & 28.2 & 17.7 & 11.2 & 9.0 \\
\hline Site 2 - Mine 6 & Pit mine & 7 & 37.2 & 29.6 & 16.6 & 7.4 & 9.2 & 13.3 \\
\hline Site 3 - Mine 6 & Dry tailing & 8 & 25.1 & 9.5 & 43.4 & 19.4 & 2.6 & 10.0 \\
\hline Site 4 - Mine 6 & Dry tailing & 7 & 10.1 & 3.8 & 40.0 & 30.0 & 16.1 & 5.7 \\
\hline Site 5 - Mine 6 & Capped tailing & 7 & 17.3 & 2.3 & 22.9 & 30.3 & 27.2 & 9.3 \\
\hline Site 6 - Mine 6 & Pit mine & 8 & 9.3 & 6.5 & 67.0 & 15.4 & 1.8 & 10.3 \\
\hline Site 1 - Mine 7 & Capped tailing & 7 & 29.6 & 27.5 & 29.3 & 10.8 & 2.8 & 12.3 \\
\hline Site 2 - Mine 7 & Dry tailing & 5 & 27.4 & 7.7 & 23.0 & 21.3 & 20.6 & 9.7 \\
\hline Site 3 - Mine 7 & Capped tailing & 5 & 16.8 & 7.2 & 24.8 & 27.5 & 23.7 & 12.0 \\
\hline
\end{tabular}




\subsection{Cluster analysis}

Hierarchical agglomerative clustering (HAC) was performed to group the sites, based on their phytosociological characteristics. Clustering was also used for the disturbed and undisturbed natural reference ecosystems (open and closed canopy), in order to assess dissimilarities with the overburdens being reclaimed. As missing values were not identified in the data array, the Euclidean distance was adopted as the dissimilarity measurement, and in defining the clusters, Ward's minimum variance method was employed.

Given the differences in dimensional size among the studied variables, it was necessary to standardize the data before performing the cluster analysis. The z-scores standardization (Eq. (2)) was adopted to achieve an equal contribution of each variable in the clustering process.

$Z_{i j}=\frac{\left(X_{i j}-X m_{j}\right)}{S_{i}}$

where $X_{i j}$ is the original data value, $X m_{j}$ is the mean for the $i^{\text {th }}$ variable, and $S_{i}$ is the standard deviation for the $i^{\text {th }}$ variable.

The cophenetic correlation coefficient was calculated after the agglomerative clustering, in order to evaluate the distortion of the dendrogram (Romesburg, 2004). The Pvclust add-on package (Suzuki and Shimodaira, 2015) of the R statistical software (R Core Team, 2016) was employed to evaluate the uncertainty in the hierarchical clustering. The approximately unbiased (AU) p-values obtained by Pvclust were used to support the group selection and the uncertainty assessment (Suzuki and Shimodaira, 2006).

To obtain the number of groups, a dendrogram cut-off was established by defining the largest width range among the groups formed in the dendrogram. This procedure enables the selection of stable clusters in the grouping process, with greater differences between groups separated by wider Euclidean distances (Romesburg, 2004).

Validation of the results and identification of phytosociological differences among the groups employed one-way analysis of variance (not assuming equal variances) and the Tukey HSD multiple comparisons test $(\alpha=5 \%)$. The means of each cluster with more than three reclamation sites were compared. Conditioning factors were evaluated using Pearson correlation analysis applied to the phytosociological variables and the soil characteristics of each reclamation site. All the statistical analyses were performed using Assistat v. 7.7 software (Silva and Azevedo, 2016) and R statistical software (R Core Team, 2016).

\section{Results}

The dendrogram obtained (Fig. 2) presented a satisfactory cophenetic correlation value (0.93), which was higher than the value considerable acceptable (0.8) by Romesburg (2004). The AU p-values standard error remained below 0.03 , with a bootstrap sample size of 10000 , as recommended by Suzuki and Shimodaira (2006) in order to obtain better results at a $95 \%$ level of confidence.

Significant AU values (> 95\%) were obtained for fifteen clusters, including several clusters that separated groups of overburdens (clusters $15,10,8,6$, and 7). The AU p-values of clusters 18 and 19 were lower, indicating higher uncertainty in their formation, and the lowest $\mathrm{AU}$ values were for clusters 11 and 12, reflecting the closely similar phytosociological characteristics of the reclaimed sites.

Classification according to the criterion of the greatest Euclidian distance at which groups could be defined (shown by the cut-off in Fig. 2) resulted in identification of three main groups. However, using this approach, several clusters with different phytosociological characteristics would have been grouped together. As revealed by application of Tukey's test, there were significant differences in the mean values for the average height and species richness for the Group 3 sites (Table 2), suggesting that for management purposes further partitioning could be required for better assessment of the phytosociological conditions. The basal area and regeneration density values showed no significant differences for any cluster, despite the different mean values obtained, with very high coefficient of variation (CV) values for clusters 10 and 15.

Site 1 of Mine 7 presented the highest basal area value, which was very different from the values obtained for all the other plots under reclamation and similar to the values for the natural references, as a result of which Ward's method placed it between clusters 16 and 15, forming cluster 17 . Nevertheless, since the values for the other variables were much more similar to cluster 10, and there was a high degree of certainty (AU p-values $>95 \%$ ) in segregating this site from the other sites in cluster 16, it was decided to place it in Group 3.1 for performance of the ANOVA analysis, resulting in a higher CV for basal area in this group.

The average height at Site 3 of Mine 8 was only 3\% lower than the value for the closed canopy reference ecosystem. The other sites that were grouped together with it (Cluster 15, Group 2) showed average height values that were slightly higher than for the open canopy forest. As expected, older sites tended to show higher average height values, resulting in a strong positive correlation among these variables (Table 3).

Species richness did not increase for older sites, resulting in a negative correlation with planting age. The highest value for the reclaimed sites was found for Site 2 of Mine 3. Nonetheless, the species richness was $45 \%$ lower than for the open canopy forest and $68 \%$ lower than for the closed canopy forest. The lowest values were found for the Cluster 10 sites, where the richness was $50 \%$ lower than for Site 2 of Mine 3. There was a moderate positive correlation with regenerating individuals, suggesting that the increase of richness could have been due to species propagation by natural regeneration processes. Since a negative correlation was obtained between species richness and average height, these results suggested that the richness derived from planted species may have decreased over time, with some species adapted to the new environmental conditions becoming taller.

For basal area, the highest value obtained in the overburdens (for Site 1 at Mine 6) was only $11 \%$ lower than that found in open canopy forest. All the other sites presented basal areas at least 58\% lower than for open canopy forest, with the lowest value (for Site 2 at Mine 5) being $98 \%$ lower. The basal area tended to be higher for sites with older planting ages, although some younger sites (such as Sites 1 and 2 of Mine 3) also showed high values, hence explaining the weak correlation. The higher values were generally associated with sites where the soil organic matter and silt clay fraction were higher, resulting in a moderate positive correlations (Table 3 ). In addition, although the regeneration densities were very different to the values for the natural areas (80\% lower for Site 6 at Mine 6, and at least 95\% lower for the other sites), results close to those for the reference ecosystems were found for the sites with higher soil silt and clay content.

Considering all the results, the clusters obtained for the overburdens could be classified into five main groups. All these groups presented very high AU p-values (>95\%), indicating a high degree of stability. The first group (Cluster 15, Group 2) showed the highest average height values, low richness, large variations in basal area, and low regeneration density values. The second group (Cluster 10, Group 3.1) showed the second highest average height values, intermediate species richness, low basal areas, and the highest individual regeneration values, despite great variability. The third group (Cluster 8, Group 3.2) showed the greatest similarity to the natural references in terms of species richness, with intermediate values for basal area and regeneration density, despite low average height values. The fourth selected group (Cluster 6, Group 3.3) showed the highest basal area values and the second highest richness values. On the other hand, it presented low values for average height and great variability in the regeneration density values. Finally, Cluster 7 (Group 3.4) showed the lowest values for all variables. 


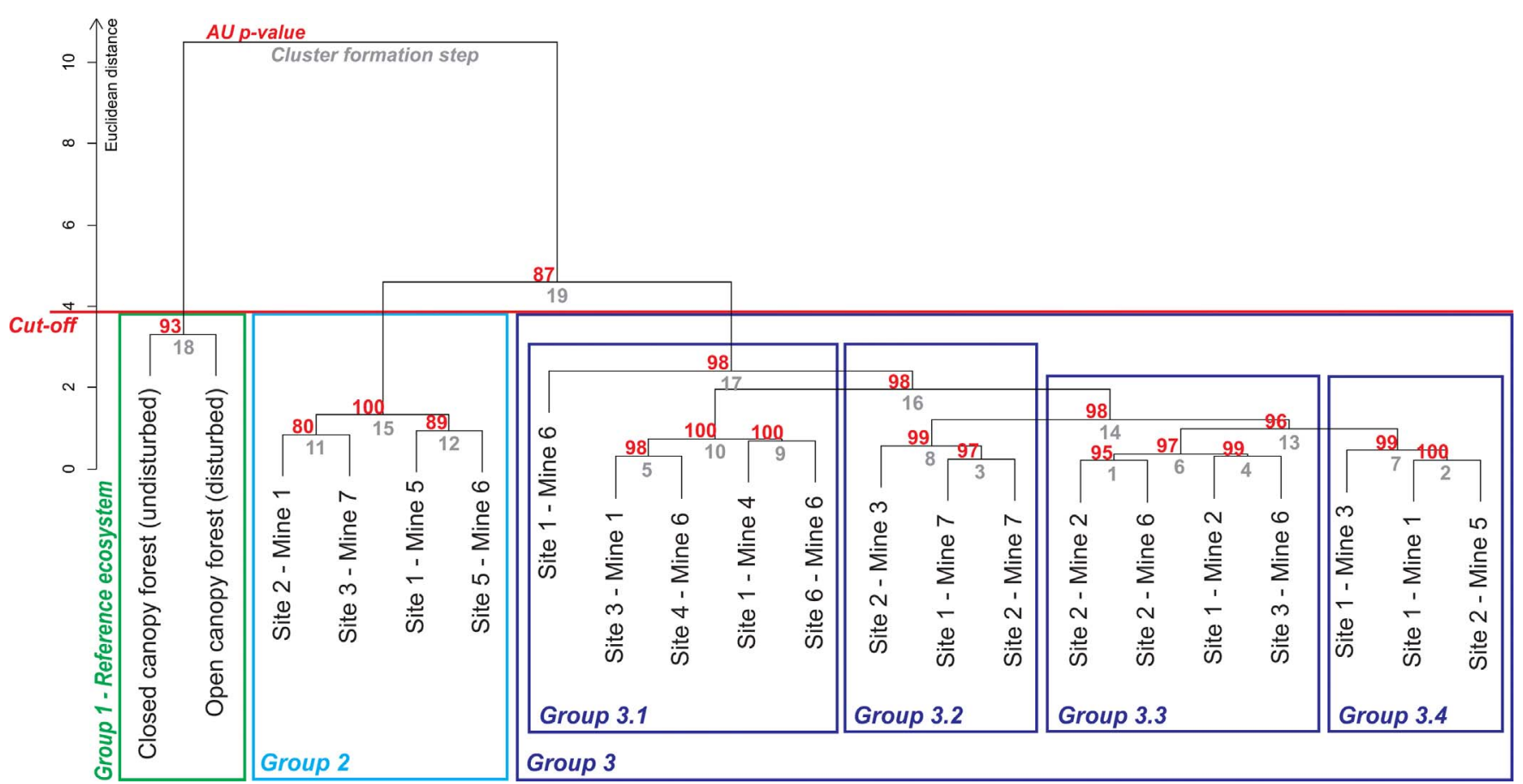

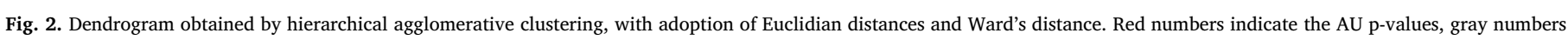

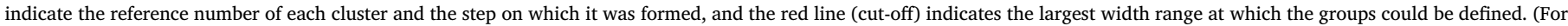
interpretation of the references to colour in this figure legend, the reader is referred to the web version of this article.)

Table 2

Results of application of ANOVA with Tukey's test to identify differences between clusters.

\begin{tabular}{|c|c|c|c|c|c|c|}
\hline Cluster & & Sites & $\begin{array}{l}\text { Average height } \\
(\mathrm{m})^{*, \#}\end{array}$ & $\begin{array}{l}\text { Species richness (species in } \\
500 \mathrm{~m}^{2} \text { ) }\end{array}$ & $\begin{array}{l}\text { Basal area }\left(\mathrm{m}^{2} /\right. \\
\text { ha })^{\#}\end{array}$ & $\begin{array}{l}\text { Naturally regenerating individuals } \\
\text { (individuals } / \mathrm{m}^{2} \text { ) }\end{array}$ \\
\hline \multirow[t]{6}{*}{15} & & Site 2 - Mine 1 & 19.00 & 4.50 & 6.22 & 0.20 \\
\hline & & Site 3 - Mine 7 & 20.00 & 5.00 & 0.89 & 0.25 \\
\hline & & Site 1 - Mine 5 & 15.00 & 5.00 & 0.43 & 0.17 \\
\hline & & Site 5 - Mine 6 & 14.00 & 3.63 & 6.35 & 0.24 \\
\hline & & Cluster mean & $14.50 \mathrm{a}$ & $4.32 \mathrm{c}$ & $3.39 a$ & $0.21 \mathrm{a}$ \\
\hline & & CV (\%) & 17.32 & 14.26 & 93.69 & 17.19 \\
\hline \multirow[t]{23}{*}{17} & \multicolumn{2}{|c|}{ Site 1 - Mine 6} & 9.00 & 5.00 & 13.25 & 0.55 \\
\hline & \multirow[t]{6}{*}{10} & Site 3 - Mine 1 & 9.00 & 7.00 & 0.96 & 0.25 \\
\hline & & Site 4 - Mine 6 & 10.00 & 9.00 & 0.55 & 0.25 \\
\hline & & Site 1 - Mine 4 & 12.00 & 7.00 & 3.33 & 0.38 \\
\hline & & Site 6 - Mine 6 & 10.67 & 8.00 & 1.31 & 1.99 \\
\hline & & Cluster mean & $11.34 \mathrm{~b}$ & $7.50 \mathrm{~b}$ & $2.32 \mathrm{a}$ & $1.19 \mathrm{a}$ \\
\hline & & CV (\%) & 12.44 & 20.60 & 137.78 & 108.24 \\
\hline & \multirow[t]{5}{*}{8} & Site 2 - Mine 3 & 5.53 & 12.50 & 2.57 & 0.60 \\
\hline & & Site 1 - Mine 7 & 6.75 & 10.00 & 1.84 & 0.25 \\
\hline & & Site 2 - Mine 7 & 8.00 & 10.00 & 1.30 & 0.29 \\
\hline & & Cluster mean & $7.38 \mathrm{c}$ & $10.00 \mathrm{a}$ & $1.57 \mathrm{a}$ & $0.27 \mathrm{a}$ \\
\hline & & CV (\%) & 18.27 & 13.32 & 33.49 & 50.41 \\
\hline & \multirow[t]{6}{*}{6} & Site 2 - Mine 2 & 5.50 & 8.00 & 3.68 & 0.13 \\
\hline & & Site 2 - Mine 6 & 6.17 & 8.00 & 4.41 & 0.51 \\
\hline & & Site 1 - Mine 2 & 6.24 & 5.50 & 4.05 & 0.15 \\
\hline & & Site 3 - Mine 6 & 7.08 & 7.00 & 3.85 & 0.69 \\
\hline & & Cluster mean & $6.66 c$ & $6.25 b c$ & $3.95 a$ & $0.42 \mathrm{a}$ \\
\hline & & CV (\%) & 10.36 & 16.58 & 7.85 & 74.51 \\
\hline & \multirow[t]{5}{*}{7} & Site 1 - Mine 3 & 5.83 & 4.00 & 2.44 & 0.10 \\
\hline & & Site 1 - Mine 1 & 4.90 & 5.50 & 0.61 & 0.38 \\
\hline & & Site 2 - Mine 5 & 6.00 & 6.00 & 0.21 & 0.26 \\
\hline & & Cluster mean & $5.45 c$ & $5.75 b c$ & $0.41 \mathrm{a}$ & $0.32 \mathrm{a}$ \\
\hline & & CV (\%) & 10.62 & 20.15 & 109.41 & 56.95 \\
\hline \multirow[t]{2}{*}{ Reference ecosystem } & \multirow{2}{*}{\multicolumn{2}{|c|}{$\begin{array}{l}\text { Closed canopy forest } \\
\text { Open canopy forest }\end{array}$}} & 23.08 & 39.73 & 27.04 & 9.61 \\
\hline & & & 14.06 & 22.49 & 14.97 & 10.26 \\
\hline
\end{tabular}

* Significant at $5 \%$ probability $(\mathrm{p}<0.05)$.

** Significant at $1 \%$ probability $(\mathrm{p}<0.01)$.

\# Normalized data (Shapiro-Wilks $\alpha=5 \%$ ), using log transformation of the original data. 
Table 3

Pearson coefficients for correlation among the phytosociological variables, planting age, soil texture, and soil organic matter of deactivated mines under reclamation (2010 data).

\begin{tabular}{|c|c|c|c|c|c|c|c|c|c|c|}
\hline & $\begin{array}{l}\text { Average } \\
\text { height }(\mathrm{m})\end{array}$ & $\begin{array}{l}\text { Species richness } \\
\left(\mathrm{Sp} . \text { in } 500 \mathrm{~m}^{2}\right)\end{array}$ & $\begin{array}{l}\text { Basal area } \\
\left(\mathrm{m}^{2} / \mathrm{ha}\right)\end{array}$ & $\begin{array}{l}\text { Naturally regenerating } \\
\text { individuals (Ind. } / \mathrm{m}^{2} \text { ) }\end{array}$ & $\begin{array}{l}\text { Planting age } \\
\text { (years) }\end{array}$ & Clay (\%) & Silt (\%) & $\begin{array}{l}\text { Very fine } \\
\text { sand }(\%)\end{array}$ & $\begin{array}{l}\text { Medium } \\
\text { sand }(\%)\end{array}$ & $\begin{array}{l}\text { Coarse } \\
\text { sand (\%) }\end{array}$ \\
\hline $\begin{array}{l}\text { Species richness (Sp. in } \\
\quad 500 \mathrm{~m}^{2} \text { ) }\end{array}$ & -0.35 & & & & & & & & & \\
\hline Basal area $\left(\mathrm{m}^{2} / \mathrm{ha}\right)$ & -0.04 & -0.12 & & & & & & & & \\
\hline $\begin{array}{l}\text { Naturally regenerating } \\
\text { individuals (Ind. } / \mathrm{m}^{2} \text { ) }\end{array}$ & -0.06 & 0.44 & 0.08 & & & & & & & \\
\hline Planting age (years) & 0.79 & -0.30 & 0.23 & -0.04 & & & & & & \\
\hline Clay (\%) & 0.23 & -0.10 & 0.59 & 0.05 & 0.06 & & & & & \\
\hline Silt (\%) & 0.07 & 0.07 & 0.41 & 0.25 & -0.07 & 0.69 & & & & \\
\hline Very fine sand (\%) & -0.05 & 0.01 & -0.19 & 0.19 & 0.04 & -0.49 & -0.15 & & & \\
\hline Medium sand (\%) & -0.05 & -0.08 & -0.46 & -0.32 & -0.06 & -0.59 & -0.76 & -0.09 & & \\
\hline Coarse sand (\%) & 0.06 & -0.12 & -0.24 & -0.35 & 0.06 & -0.25 & -0.73 & -0.46 & 0.63 & \\
\hline $\begin{array}{l}\text { Soil organic matter (g/ } \\
\left.\qquad \mathrm{dm}^{3}\right)\end{array}$ & -0.21 & -0.11 & 0.47 & -0.12 & -0.12 & 0.14 & 0.37 & 0.22 & -0.43 & -0.35 \\
\hline
\end{tabular}

Bold numbers represent significant correlations ( $\mathrm{p}<0.05)$.

\section{Discussion}

The results demonstrated that only the average height and basal area values for the restored areas were close to those found for the reference ecosystems, with species richness and natural regeneration being very different to the natural condition. In restoration ecology, the aim is to create an ecosystem that is both functional and provides habitats for many different organisms, usually targeting the condition of the preserved ecosystem (Rosenfield and Müller, 2017). In forest restoration, this usually means planting the same native species found in the reference ecosystem, aiming to create a similar community in terms of species composition (Leinfelder et al., 2015; Rodrigues et al., 2009). Although planting a large number of species may increase biodiversity to ensure that the restored site will resemble the mature forest, this does not necessarily occur, because the optimal environmental conditions needed for the development of native species may not be achieved (Rosenfield and Müller, 2017; Suganuma and Durigan, 2014; Parrotta and Knowles, 2001).

The soils of the overburdens were highly altered, with a predominance of sandy textures. Despite the considerable effort made in the forest restoration, the reestablishment of forest composition close to that of the reference ecosystems did not occur. Since the soil organic matter (SOM) was shown to influence the results in terms of basal area, with the average height increasing over time, attention to the initial actions employed to prepare mined soil (Ribeiro et al., 2015; Yada et al., 2015; Longo et al., 2011) could lead to better tree development.

However, as the species richness was only positively correlated with natural regeneration, and showed a negative correlation with planting age, the results suggested that some of the planted species may have been lost, resulting in dominance of certain species better adapted to the new environmental conditions. Furthermore, Amazonian soils typically show low natural fertility and high acidity (Costa et al., 2006; Moreira and Malavolta, 2004), and several local species require shading in order to develop (Parrotta and Knowles, 2001; Knowles and Parrotta, 1995). Prior to planting, the actions taken included use of composting, green manuring, chemical fertilizers, and liming, so the mined soils probably presented very different environments for vegetation development, compared to the natural condition.

The segregation of the reference ecosystem and the reclamation sites in the dendrogram, with grouping only at the maximum Euclidian distance, demonstrates an important aspect of the proposed methodology, namely its sensitivity in detection of these differences. This sensitivity was also shown by the finding that sites on mine substrates with a lower degree of alteration, compared to the original soil, showed characteristics that were more similar to those of the disturbed Amazon forest, associated with higher CV values within the clusters and increased uncertainty in the HAC. However, the values of the variables in the groups formed were not homogeneous, with the greatest effects shown by the average height and species richness values.

As the average height and species richness exhibited a strong correlation, the HAC analysis may have been influenced by multicollinearity (Hair et al., 2010). Therefore, in future applications of the proposed methodology, it is strongly recommended to determine the effects of the variables on each other. In cases where multicollinearity is evident, we suggest the adoption of synthetic variables using factorial analysis (Hair et al., 2010), or weighted clusters analysis (Ackerman et al., 2012; Mingoti, 2005).

The adoption of the criterion of the widest Euclidian distance led to the merging of several clusters with different phytosociological characteristics in one large group (Group 3). As considerable differences were found between the overburdens and the reference ecosystems, the magnitudes of differences among the overburdens were low by comparison, masking the differences among Groups 3.1, 3.2, 3.3, and 3.4. Therefore, adoption of the proposed methodology with uncertainty assessment was shown to be more suitable in the case study, since it provided better segregation of the mined forest sites in terms of phytosociological performance. All the selected groups presented a high degree of stability, similar characteristics among the elements contained within them, and significant differences among each other.

The results obtained here were in agreement with the findings of Knowles and Parrotta (1995), Parrotta and Knowles (2001), and Ribeiro et al. (2016) for forest restoration at mined sites in the Amazon biome. The highest values of the phytosociological parameters were similar to those observed for mined locations with lower environmental alteration, while the lowest values were similar to those for severely altered soils.

\section{Conclusions}

The findings of this work demonstrated that hierarchical clustering with uncertainty estimation is a promising approach that can be used to evaluate the outcomes of reclamation strategies under different environmental conditions. The proposed methodology was used to identify key features that provide a road map for improving forest restoration outcomes, making an important contribution to understanding the limitations involved in restoring land in the Amazon region.

The proposed technique was shown to be robust and more comprehensive than the classical approach employed to classify and understand the functionality of mined ecosystems, providing a guide for the measurement and monitoring of ecological functions with the aim of achieving a desired state.

In the case study, specific phytosociological parameters were determined in order to assess the forest restoration. However, the 
clustering based methodology could be employed in forest restoration assessment considering a variety of other measurable variables. Even synthetic variables derived from factor analysis or quality indexes could be used, with due care to avoid multicollinearity. In addition, the Tukey HSD test and Pearson correlation analysis could be replaced by nonparametric alternatives in cases of non-normal data.

The results obtained here also suggested that characteristics of the mined soils had a strong influence on the forest restoration. Such information is crucial for understanding the potential outcomes of restoration ecology practices and long-term land reclamation performance, especially since several non-obvious features were observed in the case study.

\section{Acknowledgements}

Financial support for this work was provided by CAPES (Coordenação de Aperfeiçoamento de Pessoal de Nível Superior), in the form of scholarships awarded to the first and second authors. We thank the Land Reclamation Research Group of the Sorocaba Institute of Science and Technology (UNESP, Sorocaba) for assistance, and the reviewers of Ecological Engineering for their insightful suggestions. This research is part of the first author's $\mathrm{PhD}$ thesis at the Department of Land Reclamation, Remediation, and Environmental Assessment of the Institute of Science and Technology (UNESP, Sorocaba).

\section{References}

Ackerman, M., Ben-David, S., Brânzei, S., Loker, D., 2012. Weighted clustering. In Hoffmann, J., Selman, B. (Eds.), AAAI. AAAI Press.

Balaguer, L., Escudero, A., Martín-Duque, J.F., Mola, I., Aronson, J., 2014. The historical reference in restoration ecology: re-defining a cornerstone concept. Biol. Conserv. 176, 12-20. http://dx.doi.org/10.1016/j.biocon.2014.05.007.

Bradshaw, A.D., 1984. Ecological principles and land reclamation practice. Landsc. Plann. 11, 35-48. http://dx.doi.org/10.1016/0304-3924(84)90016-9.

Bradshaw, A., 1997. Restoration of mined lands-using natural processes. Ecol. Eng. 8, 255-269. http://dx.doi.org/10.1016/S0925-8574(97)00022-0.

Bradshaw, A., 2000. The use of natural processes in reclamation-advantages and difficulties. Landsc. Urban Plann. 51, 89-100. http://dx.doi.org/10.1016/S01692046(00)00099-2.

Costa, N.L., Townsend, C.R., Magalhães, J.A., Paulino, V.T., Pereira, R.G.A., Mochiutti, S., 2006. Recuperation and renovation of degradated pastures. Rev. Electrón. Vet. 3, 9-49 In Brazilian Portuguese.

Hair Jr., J.F., Black, W.C., Babin, B.J., Anderson, R.E., 2010. Multivariate Data Analysis, 10th ed. Pearson, New York.

Halme, P., Allen, K.A., Auninš, A., Bradshaw, R.H.W., Brūmelis, G., Čada, V., Clear, J.L., Eriksson, A.M., Hannon, G., Hyvärinen, E., Ikauniece, S., Iršėnaitė, R., Jonsson, B.G., Junninen, K., Kareksela, S., Komonen, A., Kotiaho, J.S., Kouki, J., Kuuluvainen, T., Mazziotta, A., Mönkkönen, M., Nyholm, K., Oldén, A., Shorohova, E., Strange, N., Toivanen, T., Vanha-Majamaa, I., Wallenius, T., Ylisirniö, A.L., Zin, E., 2013. Challenges of ecological restoration: lessons from forests in Northern Europe. Biol. Conserv. 167, 248-256. http://dx.doi.org/10.1016/j.biocon.2013.08.029.

International Council of Mining \& Metals (ICMM), 2013. The Mining Sector in Brazil: Building Institutions for Sustainable Development. http://www.icmm.com/en-gb/ publications/the-mining-sector-in-brazil-building-institutions-for-sustainabledevelopment (Accessed 1 December 2016).

INPE-Instituto Nacional de Pesquisas Espaciais, 2015. Satélite Sino-Brasileiro de Recursos Terrestres. http://www.cbers.inpe.br/galeria_imagens/imagens_cbers4. php.

Jongman, R.H.G., Ter Braak, C.J.F, van Tongeren, O.F.R., 1995. Data Analysis in Community and Landscape Ecology. Cambridge University Press, New York.

Knowles, H., Parrotta, J.A., 1995. Amazonian forest restoration: an innovative system for native species selection based on phonological data and field performance indices. Commonw. For. Rev. 74, 231-243.

Legendre, P., Legendre, L., 2012. Numerical Ecology. Elsevier, Amsterdam.

Lei, H., Peng, Z., Yiang, H., Yang, Z., 2016. Vegetation and soil restoration in refuse dumps from open pit coal mine. Ecol. Eng. 94, 638-646. http://dx.doi.org/10.1016/ j.ecoleng.2016.06.108.

Leinfelder, R.R., Iramina, W.S., Eston, S.M., 2015. Mining as a tool for reclamation of a degraded area. Mining 68, 215-220. http://dx.doi.org/10.1590/037044672015680127.

Li, X.R., He, M.Z., Duan, Z.H., Xiao, H.L., Jia, X.H., 2006. Recovery of topsoil physicochemical properties in revegetated sites in the sand-burial ecosystems of the Tengger Desert, northern China. Geomorphology 88, 254-265. http://dx.doi.org/10.1007/ s11427-014-4633-2.

Lima, A.T., Mitchell, K., O'Connell, D.W., Verhoeven, J., Cappellen, P.V., 2016. The legacy of surface mining: remediation, restoration, reclamation and rehabilitation. Environ. Sci. Policy 66, 227-233. http://dx.doi.org/10.1016/j.envsci.2016.07.011.
Longo, R.M., Ribeiro, A.I., Melo, W.J., 2011. Recovery of degraded soils in the tin mineral exploitation: microbian biomass and dehydrogenase activity. Bragantia 70, 132-138. http://dx.doi.org/10.1590/S0006-87052011000100019. (In Brazilian Portuguese).

MMA/IBAMA-Ministério do Meio Ambiente, Instituto Brasileiro do Meio Ambiente e dos Recursos Naturais Renováveis, 2005. Plano de Manejo da Floresta Nacional do Jamari-Rondônia, Volume I, Diagnóstico. http://www.icmbio.gov.br/portal/ images/stories/docs-planos-demanejo/flona_jamari_pm_diagnostico.pdf (Accessed 1 December 2016)

Miao, Z., Marrs, R., 2000. Ecological restoration and land reclamation in open-cast mines in Shanxi Province, China. J. Environ. Manage. 59, 205-215. http://dx.doi.org/10. 1006/jema.2000.0353.

Mingoti, S.A., 2005. Análise de dados através de métodos de estatística multivariada: uma abordagem aplicada. Editora UFMG, Minas Gerais.

Monteiro, M.A., 2005. Meio século de mineração industrial na Amazônia e suas implicações para o desenvolvimento regional. Estudos Avançados 19, 187-207. http://dx.doi.org/10.1590/S0103-40142005000100012. (In Brazilian Portuguese).

Moreira, A., Malavolta, E., 2004. Dynamic of organic matter and microbial biomass in a soil under different management systems in the Western Amazon. Pesq. agropec. bras 39, 1103-1110. http://dx.doi.org/10.1590/S0100-204X2004001100008. In Brazilian Portuguese.

Mukhopadhyay, S., Maiti, S.K., Masto, R.E., 2014. Development of mine soil quality index (MSQI) for evaluation of reclamation success: a chronosequence study. Ecol. Eng. 71, 10-20. http://dx.doi.org/10.1016/j.ecoleng.2014.07.001.

Parrotta, J.A., Knowles, O.H., 2001. Restoring tropical forests on lands mined for bauxite: examples from the Brazilian Amazon. Ecol. Eng. 17, 219-239. http://dx.doi.org/10. 1016/S0925-8574(00)00141-5.

Pedlowski, M.A., Dale, V.H., Matricardi, E.A.T., Silva Filho, E.P., 1997. Patterns and impacts of deforestation in Rondônia, Brazil. Landsc. Urban Plann. 38, 149-157. http://dx.doi.org/10.1016/S0169-2046(97)00030-3.

Phillips, J., 2016. Climate change and surface mining: a review of environment-human interactions \& their spatial dynamics. Appl. Geogr. 74, 95-108. http://dx.doi.org/10. 1016/j.apgeog.2016.07.001.

R Core Team, 2016. R: A Language and Environment for Statistical Computing. R Foundation for Statistical Computing, Vienna, Austria. https://www.R-project.org/.

Ribeiro, A.I., Fengler, F.H., Longo, R.M., Medeiros, G.A., Melo, G.F., Peche Filho, A., 2015. Choice of revegetation techniques for degraded areas using environmental damage assessment in the Amazon forest, Brazil. WIT Trans. Ecol. Environ. 192, 407-417. http://dx.doi.org/10.2495/ECO150361.

Ribeiro, A.I., Longo, R.M., Fengler, F.H., Medeiros, G.A., Bressane, A., Crowley, D.E., Melo, W.J., 2016. Use of Self-Organizing Maps in the identification of different groups of reclamation sites in the Amazon Forest-Brazil. Int. J. Sustain. Dev. Plann. 11, 827-833. http://dx.doi.org/10.2495/SDP-V11-N6-827-833.

Rodrigues, R.R., Lima, R.A.F., Gandolfi, S., Nave, A.G., 2009. On the restoration of high diversity forests: 30 years of experience in the Brazilian Atlantic Forest. Biol. Conserv. 142, 1242-1251. http://dx.doi.org/10.1016/j.biocon.2008.12.008.

Romesburg, C., 2004. Cluster Analysis for Researchers. Lulu Press, North Carolina.

Rosenfield, M.F., Müller, S.C., 2017. Predicting restored communities based on reference ecosystems using a trait-based approach. For. Ecol. Manage. 391, 176-183. http://dx. doi.org/10.1016/j.foreco.2017.02.024.

Silva, F.A.S., Azevedo, C.A.V., 2016. The Assistat software version 7.7 and its use in the analysis of experimental data. Afr. J. Agric. Res. 11, 3733-3740. http://dx.doi.org/ 10.5897/AJAR2016.11522.

Smith, N.J.H., Alvim, P., Falesi, H.I., Serrão, A., 1991. Environmental impacts of resource exploitation in Amazonia. Global Environ. Change 1, 313-320. http://dx.doi.org/10. 1016/0959-3780(91)90057-Z.

Soil Survey Staff, 1999. Soil Taxonomy: A Basic System of Soil Classification for Making and Interpreting Soil Surveys, 2nd ed. Natural Resources Conservation Service, U.S. Department of Agriculture Handbook 436. U.S.D.A Soil Conservation Service, Blacksburg.

Souza, R., Viega, M., Zyl, D.V., Telmer, K., Spiegle, S., Selder, J., 2011. Policies and regulations for Brazil's artisanal gold mining sector: analysis and recommendations. J. Clean. Prod. 19, 742-750. http://dx.doi.org/10.1016/j.jclepro.2010.12.001.

Stanturf, J.A., Palik, B.J., Dumroese, R.K., 2014. Contemporary forest restoration: a review emphasizing function. For. Ecol. Manage. 331, 292-323. http://dx.doi.org/10. 1016/j.foreco.2014.07.029.

Suganuma, M.S., Durigan, G., 2014. Indicators of restoration success in riparian tropical forests using multiple reference ecosystems. Restor. Ecol. 23, 238-251. http://dx.doi. org/10.1111/rec.12168.

Suzuki, R., Shimodaira, H., 2006. Pvclust: an R package for assessing the uncertainty in hierarchical clustering. Oxf. J. 22, 1540-1542. http://dx.doi.org/10.1093/ bioinformatics/btl117.

Suzuki, R., Shimodaira, H., 2015. pvclust: Hierarchical Clustering with P-Values via Multiscale Bootstrap Resampling. R package version 2. 0-0. https://CRAN.R-project. org $/$ package $=$ pvclust.

Yada, M.M., Mingotte, F.L.C., Melo, W.J., Melo, G.P., Melo, V.P., Longo, R.M., Ribeiro, A.I., 2015. Chemical and biochemical properties of soils degraded by tin mining and in a rehabilitation phase in the Amazon Basin. Revista Brasileira de Ciência do Solo 39, 714-724. http://dx.doi.org/10.1590/01000683rbcs20140499. (In Brazilian Portuguese).

Young, T.P., Immel, D.L., Clary, J.J., 2003. The Historical Ecology Handbook: A Restorationist's Guide to Reference Ecosystems, in: D. Egan, E.A. Howell (Eds.), Island Press \& Society for Ecological Restoration, 2001, c \$55, ISBN 1-55963-745-5; b \$30, ISBN 1-55963-746-3. Journal of Environmental Management. 68, 437-438. [Book review] 10.1016/S0301-4797(03)00093-8. 